\title{
Inhibition of Radical-Initiated Polymerisation of Vinyl Acetate by Tobacco Smoke and Some Polycyclic Hydrocarbons*
}

\author{
by \\ M. H. Bilimoria, J. Johnson (Mrs.), M. A. Nisbet, and S. Schmeller (Mrs.) \\ Imperial Tobacco Products Limited, Montreal, Quebec, Canada \\ and \\ K. K. Georgieff \\ Gulf Oil Canada Ltd., Sheridan Park, Ontario, Canada
}

\section{INTRODUCTION}

There is continued interest in finding chemical or biochemical predictors of the biological activity of tobacco smoke. One approach to the problem has been to select enzymes which are responsive to smoke and to base a predictive test on enzyme inhibition (1). Published studies indicate that the inhibition is frequently due to reaction of smoke with sulfhydryl groups. Evidence for this has come from studies of inhibition of dehydrogenases by smoke ( 2 ) and from the fact that the presence of added cysteine can decrease the inhibition (3).

Our own approadh to the problem has been to develop assays for specific properties of smoke; properties which we feel are of biological importance, and are attributable to a class of compounds rather than one specific compound. An example is the redox property of smoke, which can be measured by the ability of smoke to reduce dyes (4) or oxidise ascorbate (5). Our attention was drawn to redox characteristics during some studies on the effect of smoke on biological electron transport systems. It was found that some of the disruption of the system could be ascribed to the reduction by smoke of electron acceptors such as cytochrome c.

Continuing our search for simple tests which might be related to biological activity, we have recently studied the effect of smoke on radical-initiated polymerisation of vinyl acetate. It has been shown that certain classes of compounds are capable of retarding benzoylperoxide-initiated polymerisation (6) and in fact a number of anticancer drugs have been demonstrated to have strong radical inhibitory properties (7). It could be expected that some of the reactive species in smoke would be capable of reacting with free radicals thus retarding vinyl acetate polymerisation.

Using the procedures described by Georgieff (8), we have investigated the effects of smoke and a number of pure polycyclic aromatics on this reaction and the

\footnotetext{
* Received for publication: 15th Februacy, 1973.
}

results are reported in this paper. Due to differences in apparatus, the inhibition factors obtained for certain reference compounds were somewhat lower than those found by Georgieff. However, the values were self-consistent.

\section{MATERIALS AND METHODS}

Vinyl acetate, free of stabilisers, was obtained from Gulf Oil (Canada) Ltd.. Benzoyl peroxide was crystallised from chloroform prior to use. The polyaromatic hydrocarbons were tested for purity by melting point and thin-layer chromatography; where necessary, they were crystallised to constant melting point. Glassware was scrupulously cleaned by a sequence of washings in methanolic potassium hydroxide, chromic acid, distilled water and finally methanol. The test-tubes were dried and stored in a dust-free warm-air oven.

Cigarettes and cigars were smoked to the standard regime of one $35 \mathrm{ml}$ puff of 2-second duration per minute to butt lengths of 30 and $50 \mathrm{~mm}$ respectively. Pipes were smoked on a specially constructed madhine drawing one $35 \mathrm{ml}$ puff of 2-second duration at 10-second intervals. Particulate matter was collected on weighed Cambridge filter pads for tests on unfractionated smoke. Hydrocarbon-enriched fractions were prepared by the method of Grimmer ( 9 ). For this fractionation the condensate from $50-75$ cigarettes or $30-40$ cigars was collected by electrostatic precipitation.

Solutions of potential inhibitors were prepared in vinyl acetate. When the smoke was trapped on a Cambridge filter, the entire pad was macerated in the monomer and filter fragments were removed by filtration. If smoke fractions or hydrocarbons were being tested the material was dissolved directly in vinyl acetate. The concentrated solutions were all made up to contain $5 \mathrm{mg}$ of inhibitor per $\mathrm{ml}$.

The tests were carried out in duplicate by placing $10.00 \mathrm{mI}$ vinyl acetate and $20 \mathrm{mg}$, of benzoyl peroxide in $20 \times 150 \mathrm{~mm}$ glass test-tubes; $0.00,0.01,0.03,0.05$ and 
Figure 1. Vapour-phase trapping system.

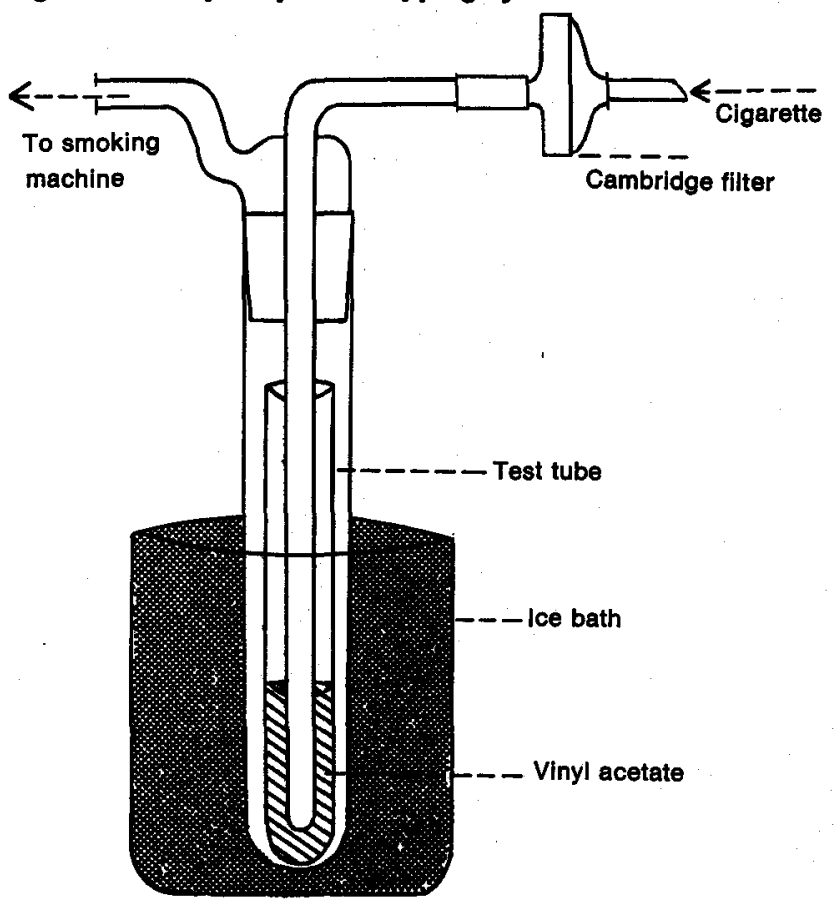

$0.07 \mathrm{ml}$ of inhibitor solution was added to the monomer peroxide mixture. The ten tubes were immersed in a constant-temperature bath at $70 \pm 0.5^{\circ} \mathrm{C}$ and the time required to reach a spontaneous boil was recorded. The presence of a control with each test set was designed to counter the effect of fluctations in bath temperature.

Figure 2. Effect of smoke vapour phase and lsoprene on the polymerisation of vinyl acetate.

Smoke vapour phase

\section{$\square$ Isoprene}

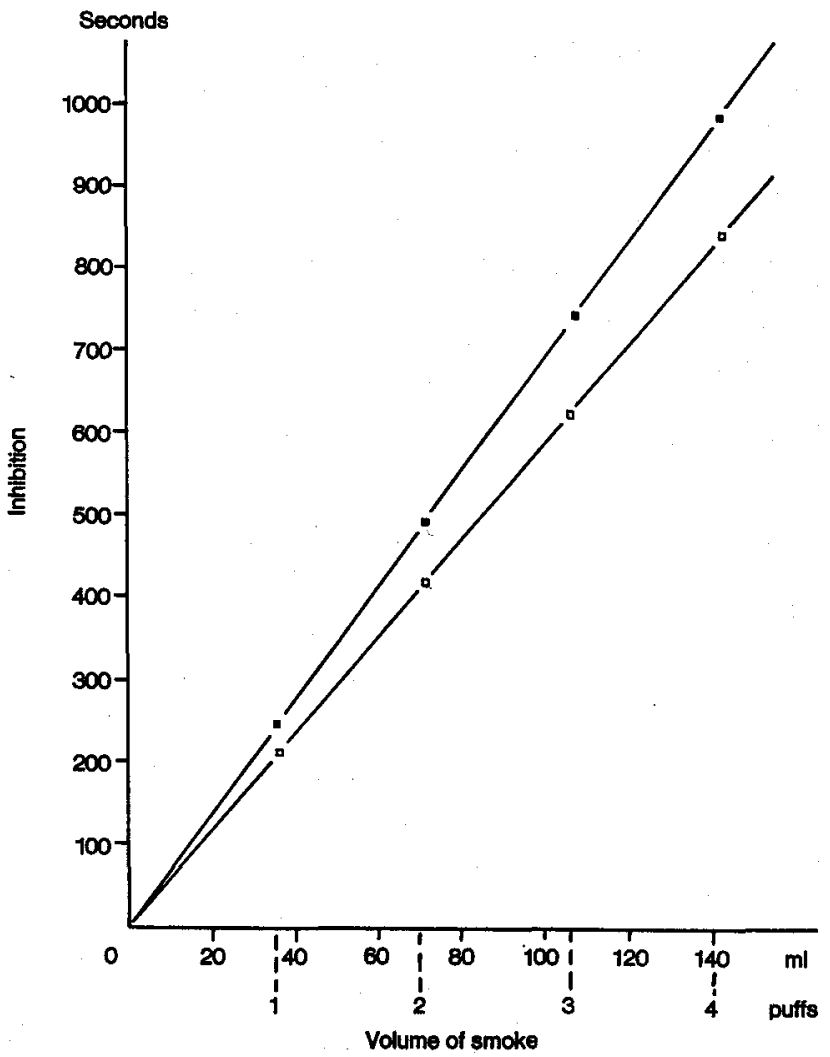

The tests on vapour-phase samples were achieved by drawing the smoke from the cigarette through a Cambridge filter directly into a prewashed test-tube containing $8.0 \mathrm{ml}$ of vinyl acetate, cooled in an ice-bath (see Fig. I). One to four puffs, excluding in all cases the lighting puff, were bubbled into the monomer. The tubes were then removed from the apparatus, $2 \mathrm{ml}$ of vinyl acetate containing $20 \mathrm{mg}$ of benzoyl peroxide were added and the mixtures were immersed in the water bath. The time required to reach a spontaneous boil was recorded. A control was derived by bubbling the appropriate number of puffs from an unlit cigarette through the trap.

Least squares lines were fitted to the data and from the slopes of the lines, the inhibition factors (delay in spontaneous boiling) expressed as minutes per ppm, were derived for solid or liquid inhibitors. In our tables, to facilitate visual comparison we have expressed the results as min. $\mathrm{ppm}^{-1} \times 10^{3}$. In the case of vapour phase the results are shown graphically as seconds per $\mathrm{ml}$ of bubbled vapour (Fig. 2).

\section{RESULTS AND DISCUSSION}

Our initial studies were directed toward smoke vapour phase which we found was an effective inhibitor of vinyl polymerisation. As can be seen from the graph in Fig. 2, one puff of smoke is capable of delaying the spontaneous boil by 240 seconds. The extent of inhibition showed a linear relationship to the number of puffs over the range which we examined.

Information as to the type of compounds in smoke vapour phase most likely to contribute to this inhibitory effect was provided by Georgieff's study of the inhibitory properties of a range of unsaturated hydrocarbons (8). He observed that a number of conjugated dienes and trienes were particularly active. The vapour phase of smoke from flue-cured tobacco contains the following dienes (10).

$\begin{array}{lc}\text { Compound } & \text { Concentration ( } 40 \mathrm{ml} \text { puff) } \\ \text { 1,3-butadiene } & 4.3 \mu \mathrm{g} \\ \text { isoprene } & 47.0 \mu \mathrm{g} \\ \text { 1,3-trans-pentadiene } & 1.2 \mu \mathrm{g} \\ \text { 1,3-cis-pentadiene } & 1.9 \mu \mathrm{g}\end{array}$

The major component, isoprene, was tested for its inhibitory activity over a range of concentrations similar to those encountered in smoke vapour (see Fig. 2). It was found to have an inhibition factor of $788 \mathrm{~min}$. $\mathrm{ppm}^{-1} \times 10^{8}$ and calculations showed that isoprene alone could account for a high percentage of the inhibitory activity of the vapour phase. If one assumes similar inhibition factors for the other conjugated dienes present, most of the retardation of polymerisation by vapour phase could be attributed to its diene content.

To confirm the hypothesis that conjugated dienes were 
the major inhibitors in smoke vapour phase, the unsaturated compounds were removed by passing the vapour through a $6 \mathrm{~cm}$ column of $7 \mathrm{~mm} \mathrm{I}$. D. containing $100 \mathrm{mg}$ of $60-80$ mesh firebrick coâted with $25 \%$ mercuric perchlorate (11) and comparing its inhibitory activity with that of vapour which had been drawn through a similar column of uncoated firebrick. The smoke vapour which had been exposed to mercuric perchlorate caused no inhibition of polymerisation. That which had been in contact with firebrick alone had the same activity as untreated vapour phase.

Nitric oxide (NO) is known to retard benzoylperoxide-initiated polymerisation of butadiene (12). Its effect on vinyl-acetate polymerisation, however, has not been reported. Nitric oxide is known to occur in the smoke from flue-cured cigarettes at levels of about 6. $\mu \mathrm{g} /$ puff (13). To determine the contribution of NO to the inhibition of vinyl acetate polymerisation by smoke vapour phase, a mixture of $363 \mathrm{ppm} N O$ in nitrogen was bubbled through the monomer. The conditions of bubbling were identical to those used for smoke vapour and the quantity of NO passed into the monomer was equivalent to that found in 6 puffs smoke vapour. The polymerisation rate of the NOtreated monomer was identical with that of the control. It can be concluded, therefore, that under our experimental conditions NO did not appear to have any inhibitory activity.

Unfractionated condensates were tested by macerating the Cambridge filter pads, on which the smoke had been trapped, in vinyl acetate and filtering the solutions to remove fragments of fibreglass. Estimates of the dry weights of material on the Cambridge filter were calculated from the predicted water content of smoke from the various sources. The smoke from a range of different tobacco types and smoking vehicles were compared for their ability to inhibit polymerisation; the results are shown in Table. 1.

Table 1. Inhlbltion of polymerisation of vinyl acetate by different tobacco-smoke condensates.

\begin{tabular}{l|c|c}
\hline Tobacco & Form & \multicolumn{2}{l}{ Inhibition factor } \\
\hline Flue-cured & Cut & 115 \\
Flue-cured & Granulated & 114 \\
Alr-cured & Granulated & 87 \\
Stem & Cut & 98 \\
Stem & Granulated & 95 \\
Perique & Granulated & 82 \\
Reconstituted & Cut & 71 \\
Reconstituted & Granulated & 66 \\
Pipe & & 33 \\
Cigar & & 90 \\
\hline
\end{tabular}

Each value represents a mean of 24 results with a coefficient of variation of $2.0 \%$.

Comparisons were made between the same tobacco types in cut and granulated form so that small samples of tobacco, of which insufficient material is available for conventional cigarette manufacture, could be included in the test series. The granulation technique consists of grinding the tobacco and collecting the fraction which passes through a number 20 and can be retained on a number 35 mesh sieve (Tyler Screen Scale). The ground material is then poured into standard-cigarette tubes with a cellulose acetate filter. The yields of particulate matter from cigarettes made in this fashion have been shown to be comparable to yields from conventional cigarettes. The results indicated that there was no significant difference in polymerisation-inhibition factors between condensates from the same tobacco in cut and granulated form.

The results also showed that flue-cured tobacco had the highest activity with a value of 115 units while pipe smoking produced the lowest, 33 units. Intermediate values were found for air-cured, stem, reconstituted tobacco sheet and perique tobacco.

Considerable significance has been attached to the presence of polyaromatic hydrocarbons in smoke. It is considered that the polyaromatics are responsible for the greater part of the tumorigenic activity of smoke as measured by mouse-skin painting (14). Smoke was processed by the method described by Grimmer (9) to yield a fraction enriched in polyaromatic hydrocarbons. A number of these fractions were prepared and tested for their inhibition factor. The results are shown in Table 2.

Table 2. Inhlbition of polymerisation by polyaromatichydrocarbon fractions obtalned from tobacco-smoke condensates.

Source of fraction Inhibition factor

Flue-cured 101

Toluene-extracted flue-cured tobacco

98

Acetone-extracted flue-cured tobacco

112

Cicar 1

Cigar 2

Cigar 3

112

105

106

It can be seen from the Table that the enriched fractions did not have greater inhibitory activity per ppm than whole smoke. Analysis of variance indicated that no significant differences existed between the fractions derived from various tobacco types. The low activity encountered here may be due to the presence of inert materials, such as aliphatic hydrocarbons, which do not inhibit polymerisation or due to the fact that the aromatic hydrocarbon mixture found in smoke (15) is not strongly inhibitory. We plan to purify this fraction further in the hope of detecting qualitative differences between smoke from different sources.

A basis for comparison has been provided by investigating the inhibition factors of some aromatic hydrocarbons including both carcinogenic and non-carcinogenic compounds. Table 3 summarises the results.

The carcinogenicity ratings given to the compounds tend to be subjective since the hydrocarbons have not 
Table 3. Carcinogenicity of compounds and their ablity to Inhlbit radical-Initiated polymerisation of vinyl acetate.

\begin{tabular}{|c|c|c|}
\hline & $\underset{\text { city }}{\text { Carcinogeni- }}$ & $\frac{\text { Inhibition factor }}{\text { min.ppm-1 } \times 10^{9}}$ \\
\hline Phenanthrene & + & 12 \\
\hline Naphthalene & + & 47 \\
\hline 4,5-Benzopyrene & + & 53 \\
\hline Chrysene & + & 70 \\
\hline Pyrene & + & 141 \\
\hline 1,2,5,6-Dibenzanthracene & + & 149 \\
\hline 20-Methylcholanthrene & +++ & 273 \\
\hline 1,2-Benzanthracene & $+t$ & 352 \\
\hline 9-10-Dimethylanthracene & + & 382 \\
\hline Fluoranthene & 0 & 396 \\
\hline 3,4-Benzopyrene & +++ & 455 \\
\hline Anthracene & + & 494 \\
\hline 9-Methylanthracene & 0 & 697 \\
\hline $\begin{array}{l}\text { 9,10-Dimethyl-1,2-benzan- } \\
\text { thracene }\end{array}$ & +++ & 869 \\
\hline
\end{tabular}

+++ Active carcinogens, + Weak carcinogens

" Source: "Survey of compounds which have been tested for carcinogenlc activity", Second Ed. (1951) \& Supplement 2 (1969), $\mathrm{NCl}$.

usually been tested for tumorigenic activity under the same experimental conditions. No direct correlation can be drawn between the ability of the hydrocarbon to inhibit vinyl polymerisation and carcinogenicity. It can be observed, however, that the active carcinogens all have high inhibition factors ranging from 273 units for 20-methylcholanthrene to 869 units for 9,10dimethyl-1,2-benzanthracene. Weak carcinogens tend to have lower activities. Some compounds, for example 9methylanthracene, do demonstrate a high ability to react with radicals formed during polymerisation, but fail to behave as active carcinogens.

An explanation of why some aromatics are so much more prone to addition of free radicals has been given by Coulson (16) who has calculated localisation energies for a number of aromatic hydrocarbons. The "preparedness" of the hydrocarbon to react with an approaching radical to form a new $\mathrm{C}-\mathrm{C}$ bond depends on the ease with which an electron can be localised in the hydrocarbon. Szwarc (17) has confirmed this work experimentally by measuring the rates of addition of methyl radicals to aromatic compounds. It was demonstrated that the logarithms of methyl affinities are linearly related to localisation energies and also, that the logarithm of the relative rate constants of addition of any radical $R \cdot$ to a series of aromatic hydrocarbons bears a linear relationship to localisation energies.

The relative abilities of the aromatic hydrocarbons to inhibit vinyl polymerisation generally parallel their relative reactivities toward methyl radicals as determined by Szwarc.

As a basis for interpreting our results with smoke and aromatic hydrocarbons, an explanation must be given of the type of reaction under study. The reaction mechanism in the presence of an added retarder has been given by Kice (18).
Stage

Initiation
Propagation
Transfer or addition
Copolymerisation

Termination

\section{Mechanism}

$\mathrm{I} \rightarrow \mathbf{2} \mathbf{R}$.

P. $+X \rightarrow Z$.

$\mathrm{Z} \cdot \mathrm{M} \rightarrow \mathrm{P}$.

$\mathrm{Z} \cdot+\mathrm{P} \cdot \rightarrow$ Inactive polymer

$Z \cdot+Z \cdot \rightarrow$ Inactive product

P. + P. $\rightarrow$ Inactive polymer
$R \cdot+\mathrm{M} \rightarrow \mathrm{P}$.

$\mathrm{I}=$ initiator, $\mathrm{R} \cdot=$ initiator radical, $\mathrm{M}=$ monomer,

$\mathrm{X}=$ retarder, $\mathrm{P} \cdot=$ polymer radical, $\mathrm{Z} \cdot=$ radical formed by the reaction of P. with retarder $X$.

Three types of reaction can be involved in the retardation process.

\section{Addition or Substitution}

Some substances react with radicals to produce another radical which may be too stable to enter the kinetic chain or is reactive along a different pathway. Examples of this type of reaction have been quoted by Szwarc (19) who studied the reactivity of aromatic hydrocarbons toward methyl radicals generated from acetyl peroxide.

$\mathrm{R} \cdot+\mathrm{C}_{6} \mathrm{H}_{6} \rightarrow \mathrm{RC}_{6} \mathrm{H}_{6}$.

Substitution

$\mathrm{RC}_{6} \mathrm{H}_{6} \cdot \mathrm{R} \cdot \rightarrow \mathrm{RC}_{6} \mathrm{H}_{5}+\mathrm{RH}$

Addition

$\mathrm{RC}_{6} \mathrm{H}_{6} \cdot+\mathrm{R} \cdot \rightarrow$<smiles>[R]C1C=CC=CC1</smiles>
or<smiles>[R]C1C=CCC=C1</smiles>

2. Atom Transfer

The most commonly encountered transfer is of hydrogen which takes place from compounds such as phenols or amines and other materials with active hydrogen.

$$
\mathrm{R} \cdot+\mathrm{H}-\mathrm{D} \rightarrow \mathrm{RH}+\mathrm{D}
$$

HD represents a hydrogen donor; $D$ - is unable to generate a new radical from a monomer molecule.

\section{Inhibition by Radicals}

Added free-radical species can intercept the radicals formed during the polymerisation process and produce inactive products. An example of this inhibition type was demonstrated by Bartlett (6) who showed that diphenylpicrylhydrazyl, a stable free radical, was a very effective inhibitor of radicalinitiated vinyl polymerisation.

The reaction can be described by the equation:

$$
R \cdot+X \cdot \rightarrow R X
$$

where $R \cdot$ represents any free-radical chain carrier and $R X$ is an inactive product. 
Table 4. Mechanlems of inhlbition of radical-initlated poIymerisation of vinyl acetate.

\begin{tabular}{|c|c|c|}
\hline $\begin{array}{l}\text { Inhibition } \\
\text { mechanism }\end{array}$ & $\begin{array}{l}\text { Reactive } \\
\text { species }\end{array}$ & Examples in smoke \\
\hline $\begin{array}{l}\text { Addlition/substi- } \\
\text { tution }\end{array}$ & $\begin{array}{l}\text { Double bonds } \\
\text { Aromatic nuclei }\end{array}$ & $\begin{array}{l}\text { Unsaturated hydrocarbons } \\
\text { Aromatic and polyaromatic } \\
\text { compounds }\end{array}$ \\
\hline Atom transfer & Active hydrogen & $\begin{array}{l}\text { Phenols } \\
\text { Amines } \\
\text { Reducing agents } \\
\text { Olefins }\end{array}$ \\
\hline $\begin{array}{l}\text { Inhibition } \\
\text { by radicals }\end{array}$ & Radicals & $\begin{array}{l}\text { Resonance-stabilised } \\
\text { smoke radicals }\end{array}$ \\
\hline
\end{tabular}

The information about the three mechanisms of inhibition enables us to predict the classes of smoke components, which may be responsible for retarding vinyl-acetate polymerisation. This is shown in Table 4 .

More specific information about inhibitory compounds in smoke can be derived from the systematic studies by Georgieff (20) on substances which retard benzoylperoxide-initiated vinyl-acetate polymerisation. A selection of his findings is given in Table 5.

As Table 5 indicates, many of the active inhibitors tested by Georgieff have been detected in smoke. Chlorobutadiene and hexatriene have not been detected.

Table 5. Inhibltion of polymerisation by compounds and their occurrence in tobacco smoke.

\begin{tabular}{|c|c|c|}
\hline Compound & $\frac{\text { Inhibition factor (20) }}{\text { min.ppm-1 }}$ & $\begin{array}{c}\text { Present } \\
\text { in smoke } \\
\text { (15) }\end{array}$ \\
\hline \multicolumn{3}{|l|}{ Unsaturated hydrocarbons: } \\
\hline Hexene-1 & 2 & + \\
\hline 1,5-Hexadiene & 9 & - \\
\hline 4-Chloro-1,3-butadiene & 521 & - \\
\hline trans-1,3,5-hexatriene & 1570 & - \\
\hline \multicolumn{3}{|l|}{ Phenols: } \\
\hline Hydroquinone & 1010 & + \\
\hline p-tert-Butylcatechol & 920 & + \\
\hline 1,2,4-Trihydroxybenzene & 1010 & + \\
\hline \multicolumn{3}{|l|}{ Quinones: } \\
\hline p-Benzoquinone & 830 & + \\
\hline \multicolumn{3}{|l|}{ Amines: } \\
\hline Diphenylamine & 770 & + \\
\hline 1-Naphthylamine & 700 & + \\
\hline \multicolumn{3}{|l|}{ Carbonyl compounds: } \\
\hline Acetaldehyde & 13 & + \\
\hline Crotonaldehyde & 62 & + \\
\hline Acetone & 1 & + \\
\hline \multicolumn{3}{|l|}{ Sulphur compounds: } \\
\hline Thiophene & 3 & + \\
\hline Benzene thiol & 100 & + \\
\hline \multicolumn{3}{|l|}{$\begin{array}{l}\text { Stable Free Radicals: } \\
\text { 2,2-Diphenyl-1-picryl- }\end{array}$} \\
\hline hydrazyl & 1170 & - \\
\hline
\end{tabular}

However, other conjugated unsaturated compounds are known to be present (10) and inhibition due to this class of compounds could be expected. The free-radical diphenylpicrylhydrazyl is not known to exist in smoke but other resonance-stabilised radical species do occur and have been demonstrated colorimetrically (21) and by ESR spectra (22). They are sufficiently stable to exist for several days in smoke condensates.

Our extension of Georgieff's test to include a range of polyaromatic hydrocarbons indicates that some polycondensed compounds, particularly carcinogens, have high inhibition factors. However, the concentration of these materials in smoke is probably too low to make a major contribution to the observed activity.

Our results to this point indicate that smoke vapour phase is an efficient inhibitor of vinyl-acetate polymerisation and that conjugated dienes, chiefly isoprene, are probably responsible for this activity.

The particulate matter presents a more complex picture. It is a relatively strong inhibitor and we find that smokes from different tobacco types and smoking vehicles have significantly different activities. The test which we are studying is basically a measure of the ability of smoke to intercept free radicals formed during vinyl polymerisation and thus disrupt the chain process. Consideration of the mechanisms of radical interception and the types of compounds known to retard polymerisation, suggests that all three mechanisms, addition, atom transfer and free-radical coupling, contribute to the inhibitory action of smoke. The information which we have obtained to date does not enable us to decide which, if any, is dominant. Further investigation of the mechanisms is planned.

\section{SUMMARY}

A wide range of organic compounds, which are capable of intercepting free-radical intermediates formed during radical-initiated vinyl-acetate polymerisation, have a marked impact on the rate of polymerisation of viny] acetate. The efficiency with which a compound retards polymerisation can be estimated by measuring the time it takes for a mixture of monomer and benzoyl peroxide immersed in a water-bath at $70^{\circ} \mathrm{C}$, to reach a spontaneous boil and comparing it with the time required for a similar mixture with added retarder to reach boiling point.

We have tested the efficiency of smokes from various sources as inhibitors as well as a range of polycyclic hydrocarbons. Smoke vapour is strongly inhibitory and the activity has been attributed to conjugated dienes chiefly isoprene. Smoke condensates from different tobacco types can be differentiated by their relative efficiencies in retarding polymerisation. Fluecured tobacco smoke has the highest activity; smoke from reconstituted tobacco has the lowest; air-cured, stem and perique tobacco have intermediate values. The effect of the smoking vehicle was measured by testing cigar and pipe-smoke condensates. The former 
has a value similar to air-cured tobacco but the latter has a very low activity.

Of the polycyclics which we scanned, carcinogenic substances generally showed higher activities than noncarcinogens. Some weak carcinogens such as anthracene were, however, unexpectedly active inhibitors.

A polyaromatic-hydrocarbon-enriched fraction of smoke did not appear any more active than a crude condensate.

The mechanisms by which smoke inhibits polymerisation are discussed. All three possible mechanisms - substitution reactions, atom transfer and radical coupling probably occur. It is not possible at this point to suggest which is the dominant one.

\section{ZUSAMMENFASSUNG}

Eine große Zahl organischer Verbindungen, die in der Lage sind, intermediäre freie Radikale abzufangen, die bei radikal-gestarteter Polymerisation von Vinylacetat entstehen, üben auf die Polymerisationsgeschwindigkeit bei Vinylacetat einen merklichen Einhuß aus. Es läßt sich abschätzen, in welchem $\mathrm{MaRe}$ eine Verbindung die Polymerisation verzögert, indem man die Zeit bestimmt, die eine in einem Wasserbad von $70^{\circ} \mathrm{C}$ erwärmte Mischung von Monomer und Benzoylperoxid bis zum spontanen Sieden braudht, und diesen Zeitraum mit demjenigen vergleicht, den eine ähnliche Mischung mit einem zugesetzten Reaktionsverzögerer bis zum Erreichen des Siedepunktes braucht.

Die Autoren untersuchten die Hemmwirkung von Raucharten verschiedenen Ursprungs wie auch von einer Reihe polycyclischer Kohlenwasserstoffe. Die Dampfphase des Rauches hemmt in starkem Maße, was der Aktivität konjugierter Diene, vor allem Isopren, zugeschrieben wird. Rauchkondensate verschiedener Tabakarten können durch den Grad der Hemmwirkung, die sie jeweils auf die Polymerisation ausüben, voneinander unterschieden werden. Rauch von röhrengetrocknetem Tabak hat die stärkste und Rauch von Tabakfolie die geringste Aktivität. Rauth von luftgetrocknetem Tabak, von Tabakrippen und von Perique-Tabak ergibt mittlere Werte. Zigarrenrauchkondensat zeigt Werte, die denen von luftgetrocknetem Tabak gleichen; die Wirkung von Pfeifenrauchkondensat erwies sidh als sehr gering.

Bei der Untersudhung der polycyclischen Kohlenwasserstoffe zeigte es sich, daB im allgemeinen die karzinogenen Substanzen eine stärkere Hemmwirkung ausüben als Substanzen, die nicht karzinogen sind. Einige schwache Karzinogene, wie z. B. Anthracen, hatten jedoch eine unerwartet starke Aktivität.

Eine mit polycyclischen Kohlenwasserstoffen angereicherte Kondensatfraktion zeigte keine stärkere Hemmwirkung als Rohkondensat.

Die Mechanismen, durch die der Rauch die Polymerisation hemmt, werden diskutiert. Die drei Möglich:keiten - Substitutionsreaktionen, Disproportionierung (Übertragung von Atomen) und Kopplung von Radi- kalen - treten wahrscheinlich auf. Beim gegenwärtigen Stand der Untersudhungen Jäßst sich nicht sagen, welche Reaktion vorherrscht.

\section{RESUME}

Un vaste dhojx de composés organiques capables d'intercepter des radicaux libres intermédiaires formés lors de la polymérisation radicalaire initiée de l'acétate de vinyle ont un effet marqué sur le taux de polymérisation de l'acétate de vinyle. L'efficacité d'un composé à retarder la polymérisation peut être mesurée en comparant le temps requis par une solution de monomère et de peroxyde de benzoyle, plongée dans un bain à $70^{\circ} \mathrm{C}$, pour atteindre son point d'ébullition spontanée, au temps requis par un mélange similaire additionné d'un retardateur pour atteindre son point d'ébullition.

Nous avons examiné l'efficacité de fumées de sources variées ainsi que certains hydrocarbures polycycliques en tant qu'inhibiteurs. La vapeur de fumée est fortement inhibitrice; son activité a été attribuée à des diènes conjugués, principalement l'isoprène. Des condensats de fumée provenant de différentes sortes de tabac peuvent être différenciés selon leur efficacité respective à retarder la polymérisation. La fumée de tabac flue-cured a la plus grande activité; la fumée de tabac reconstitué a la plus basse activité; les tabacs air-cured, périque, et de tige, ont des activités moyennes. L'effet de la forme du produit fumé a été mesuré en expérimentant sur des condensats de fumée de cigares et de pipes. Le premier donne des résultats semblables au tabac air-cured, mais le dernier possède une activité très basse.

Parmi les polycycliques examinés, les composés carcinogènes démontrent une plus grande activité que les composés non carcinogènes. Quelques carcinogènes considérés comme faibles, tel l'anithracène, ont toutefois réagi comme de puissants inhibiteurs.

Une fraction de fumée enridhie en hydrocarbures polyaromatiques ne s'est pas montrée plus active que le condensat brut.

Les méchanismes par lesquels la fumée inhibe Ja polymérisation sont discutés. Les trois méchanismes possibles: les réactions de substitution, le transfert d'atomes, et le couplage de radicaux, ont probablement tous liea. Il est impossible de déterminer pour le moment le méchanisme dominant.

\section{REFERENCES}

1. Busse, R. F.: Tobacco Chem. Res. Conf., Durham, N.C., 1967.

2. Benedict, R. C., and R. L. Stedman: Tobacco Sci. XIII (1969) 166.

3. Benedict, R. C, and R. L. Stedman: Experientia 24 - (1968) 1205.

4. Bilimoria, M. H., and M. A. Nisbet: Beiträge zur Tabakf. 6 (1971) 27. 
5. Bilimoria, M. H., and M. A. Nisbet: Beiträge zur Tabakf. 6 (1971) 32.

6. Bartlett, P. D., and H. Kwart: J. Amer. Chem. Soc. 72 (1950) 1051.

7. Georgieff, K. K.: Science 173 (1971) 537.

8. Georgieff, K. K., K. G. Blaikie, and R. C. White: J. Appl. Polymer Sci. 8 (1964) 889.

9. Elmenhorst, H., and G. Grimmer: Z. Krebsforsch. 71 (1968) 66.

10. Elmenhorst, $H_{\text {., }}$ and Ch. Schulz: Beiträge zur Tabakf. 4 (1968) go.

11. Newsome, J. R., V. Norman, and C. H. Keith: Tobacco Sci. IX (1965) 102.

12. Graham, W., and C. A. Winkler: Can. J. Res. 26B (1948) 564 .

13. Scherbak, M. P., and T. A. Smith: Analyst 95 (1970) 964.

14. Dontenwill, W., H. Elmenhorst, H. P. Harke, G. Reckzeh, K. H. Weber, J. Misfeld, and J. Timm: Z. Krebsforsch. 73 (1970) 305.
15. Stedman, R. L.: Chem. Rev. 68 (1968) 153.

16. Coulson, C. A.: J. Chem. Soc. 1955, 1435.

17. Szwarc, M.: J. Phys. Chem. 6 I (1957) 40.

18. Kice, J. L.: J. Amer. Chem. Soc. 76 (1954) 6274.

19. Levy, M., and M. Szwarc: J. Amer. Chem. Soc. 77 (x955) 1949.

20. Georgieff, K. K.: J. Appl. Polymer Sci. 14 (1970) 1907.

21. Takeshita, T., and H. Ohe: Nippon Senbai Kosha Chuo Kenkyusho Kenkyo Hokoku, No. 106, 163, 1964 .

22. Lyons, M. J., J. E. Gibson, and D. J. E. Ingram: Nature 181 (1958) 1003.

The authors' address:

Imperial Tobacco Products Ltd., Research and Development, P.O. Box 6500, 3810 St. Antoine Street, Montreal 101/207, Quebec, Canada. 